\title{
Photodynamic Inactivation of the Na,K-ATPase Occurs via Different Pathways
}

\author{
F. Killig, G. Stark, H.-J. Apell \\ Department of Biology, University of Konstanz, 78457, Konstanz, Germany
}

Received: 19 March 2004/Revised: 13 July 2004

\begin{abstract}
The photodynamic, i.e., the light-induced, inactivation of the $\mathrm{Na}, \mathrm{K}-\mathrm{ATPase}$ in the presence of the sensitizer rose bengal was studied under different conditions. The shape of inactivation curves of the enzyme activity was analyzed as well as partial reactions of the pump cycle. Both experimental approaches showed the existence of two different time constants of inactivation of the ion pump, which reflect two pathways of a photodynamic modification. This is supported by the following observations: (1) The amplitude of the initial fast decay of enzyme activity was enhanced in the presence of $\mathrm{D}_{2} \mathrm{O}$ and reduced in the presence of the singlet oxygen scavenger imidazole. (Similar results were found for the SR Ca-ATPase.) (2) Contrary to the fast enzyme inactivation the slow process shows an inverse doserate behavior. (3) Inactivation of the partial reactions of $\mathrm{Na}^{+}$-binding and of $\mathrm{K}^{+}$-binding to the membrane domain of the $\mathrm{Na}, \mathrm{K}$-ATPase showed only a single time constant, which corresponded to the slower time constant of enzyme inactivation. In the presence of high concentrations of singlet oxygen the fast time constant dominated the inactivation of the ATP-induced partial reaction for which the cytoplasmic domains of the enzyme play an important role. The data support the conclusion that fast inactivation is due to modification of the cytoplasmic domains and slow inactivation due to modifications of the membrane domain of the ion pumps.
\end{abstract}

Key words: Photodynamic Inactivation - Ion pump - Fluorescent dye - Singlet oxygen - Inverse doserate behavior

\section{Introduction}

Oxidative membrane damage is considered as an important part of cellular modifications following illumination of cells with visible light in the presence of certain photosensitizers (Penning et al., 1994; Moore et al., 1997). The so-called photodynamic effects occur in the presence of photosensitizers, oxygen and light, and finally lead to cell death. Photodynamic effects form the basis of a series of clinical applications such as the photodynamic therapy (Dougherty et al., 1998). They are largely due to the generation of highly reactive oxygen species such as singlet oxygen and the superoxide radical, which have been found to interact with many cellular targets (Foote, 1976). In the case of membranes, lipid peroxidation is an important consequence of singlet oxygen, $\mathrm{O}_{2}^{1}$, formation (Grossweiner \& Goyal, 1984; Girotti, 1990, 2001). Oxidative membrane damage is of great pathological importance and is discussed in relation with the phenomena of ischemia/reperfusion (and the pathogenesis of myocardial and cerebral tissue injury) and of central nervous system trauma and shock (Hall \& Braughler, 1989, Braughler \& Hall, 1989, Brown \& Hall, 1992, Kukreja \& Hess, 1992).

The present communication analyzes the photodynamic inactivation of the Na,K-ATPase, an important active ion-transport protein of the plasma membrane of almost all animal cells. For comparison, a few experiments were performed with the sarcoplasmic Ca-ATPase, which controls muscle relaxation and structurally is a closely related ion pump. In view of their potential importance for the reperfusion damage of the ischemic heart, the oxidative modification of the Na,K-ATPase and of the SR Ca-ATPase has been repeatedly studied by various groups. Different oxidation procedures have been applied in order to simulate the situation in vivo. Apart from the photodynamic generation of singlet oxygen (Vinnikova, Kukreja \& Hess, 1992, 
Penning et al., 1994; Ishibashi, Lee \& Okabe 1996), Fenton or Fenton-like reactions were frequently used (Mishra et al., 1989; Thomas \& Reed, 1990; Chen et al., 1992; Rohn, Hinds \& Vincenzi, 1993, 1996; Huang et al., 1994; Shao et al., 1995). Alternatively, the enzymes were exposed to various reactive oxygen species such as the superoxide anion generated by xanthine oxidase (Elmoselhi et al., 1994), to hydrogen peroxide (Boldyrev \& Kurella, 1996), to hypochlorous acid (Kato et al., 1998) or to free radicals of water radiolysis (Hitschke et al., 1994; Mense, Stark \& Apell, 1997).

There seems to be general agreement among the different groups that two fundamentally different reaction pathways lead to the inactivation of the ion pumps considered: direct interaction of reactive oxygen species with the enzyme and an indirect pathway, i.e., the interaction of the enzymes with products of lipid peroxidation (initiated by the reactive oxygen species). Distinction between both pathways is difficult in general, since the Na,K-ATPase is an integral membrane protein that is only active in the presence of a sufficient amount of lipids, the lipid annulus surrounding the protein. Therefore, reactive oxygen species at least in principle have the chance to react with both, the protein and the surrounding lipid.

In this study photodynamic modifications are analyzed for the first time at the level of the partial reactions of the pump cycle of the Na,K-ATPase. The results are compared with the shape of inactivation curves of the enzyme activity under different conditions. Both types of approaches show the existence of two different inactivation pathways of the two enzymes. Evidence is presented that fast inactivation is due to singlet oxygen-induced modification of the cytoplasmic domains and slow inactivation by modification of the membrane domain of the ion pumps.

\section{Materials and Methods}

\section{MATERials}

Sodium dodecylsulfate (SDS) was obtained from Pierce Chemical. Phosphoenolpyruvate, pyruvate kinase, lactate dehydrogenase, NADH and ATP (disodium salt, special quality) were from Boehringer, Mannheim, Germany; Rose bengal was from Aldrich, Taufkirchen, Germany. The fluorescent dye RH421 and the chelator BAPTA (1,2bis(2-aminophenoxy)-ethane-N,N, $N^{\prime}, N^{\prime}$ tetrasodium salt) were ordered from MoBiTec, Göttingen, Germany. TRIZMA-maleate, thapsigargin, and superoxide dismutase were purchased from Sigma (Munich, Germany). Dye purity was checked by thin-layer chromatography. Dioleoyl and diphytanoyl lecithin were obtained from Avanti Polar Lipids Inc., Alabaster, Al All other reagents were the highest grade commercially available.

\section{Enzyme Preparations and Reconstitution}

$\mathrm{Na}, \mathrm{K}-\mathrm{ATPa}$ e was prepared from the outer medulla of rabbit kidneys in the form of open membrane fragments using procedure
C of Jørgensen (1974). Because of reasons discussed below, imidazole in the buffer solutions was replaced by TRIZMA maleate in many experiments. Protein concentration was assessed by the Lowry method, using bovine serum albumin as a standard. Specific ATPase activity was determined by the pyruvate kinase/lactate dehydrogenase assay (Schwartz et al., 1971). The specific activity was in the range of 1900 to $2200 \mu \mathrm{M} \mathrm{P}_{\mathrm{i}}$ per $\mathrm{mg}$ protein and $\mathrm{h}$ at $37^{\circ} \mathrm{C}$. Trypsin-digested protein, so-called $19 \mathrm{kDa}$ membranes, was prepared according to Capasso et al. (1992). SR Ca-ATPase was prepared by a slight modification of the method of Heilmann et al. (1977) from psoas muscle of rabbits. The Ca-ATPase-specific activity was about $100 \mu \mathrm{M} \mathrm{P}_{\mathrm{i}}$ per $\mathrm{mg}$ protein and $\mathrm{h}$ at $37^{\circ} \mathrm{C}$ and could be increased up to $160 \mu \mathrm{M} \mathrm{P}_{\mathrm{i}}$ per mg protein and $\mathrm{h}$ in the presence of A23187 to short-circuit the SR membranes for $\mathrm{Ca}^{2+}$.

In some of the experiments $\mathrm{H}_{2} \mathrm{O}$ was replaced by $\mathrm{D}_{2} \mathrm{O}$. The exchange of solvent was performed by dialysis of $100 \mu$ aliquots of enzyme solution ( $2 \mathrm{mg} / \mathrm{ml}$ protein) in a dialysis tubing (Serva Visking ${ }^{\circledR}$ dialysis tubing $8 / 32$ ) against $45 \mathrm{ml}$ of $\mathrm{D}_{2} \mathrm{O}$ standard buffer with TRIZMA-maleate under slow stirring for $24 \mathrm{~h}$.

$\mathrm{Na}, \mathrm{K}-\mathrm{ATPa} e-$ containing vesicles were prepared using pure synthetic lipids, dioleoyl-or diphytanoyl lecithin according to the prescription published by Apell et al. (1985). Preparation of SR CaATPase-containing vesicles was performed by a slightly modified version of the method of Lévy et al. (1992) and Yu et al. (1993).

\section{IRRADIATION EXPERIMENTS}

Photodynamic modifications of the ATPase preparations were produced in the following way. $10 \mu \mathrm{l}$ of a $\mathrm{Na}, \mathrm{K}$-ATPase (or SR Ca-ATPase)-containing membrane preparation (protein contents 2-3 mg/ml) in standard buffer (25 mm TRIZMA-maleate or 25 mm imidazole, 1 mm EDTA, $1 \%$ sucrose, $\mathrm{pH}$ 7.5) were mixed with $10 \mu \mathrm{l}$ of rose bengal solution in the respective buffer. The final concentration of this photosensitizer was varied between 1 $\mu \mathrm{M}$ and $100 \mu \mathrm{M}$. The resulting volume of $20 \mu \mathrm{l}$ of enzyme solution was sucked up in a $100 \mu \mathrm{l}$ disposable glass micro pipette (Brand, Wertheim, Germany). The length of the liquid column in the horizontally mounted pipette was about $13 \mathrm{~mm}$, which was small enough to be homogeneously illuminated by a $12 \mathrm{~V}$ halogen lightsource ( $60 \mathrm{~W}$, Osram, Munich, Germany). The applied irradiance was $84 \mathrm{~mW} / \mathrm{cm}^{2}$, if not mentioned otherwise. The light spectrum was limited to the visible range $(350 \mathrm{~nm}-800 \mathrm{~nm})$ by appropriate UV and IR cut-off filters. Typically, irradiation was performed at room temperature $\left(20^{\circ} \mathrm{C}\right)$, however, the setup could be cooled to $0^{\circ} \mathrm{C}$ to prevent thermal inactivation of the protein preparation, which was necessary especially in the case of the $19 \mathrm{kDa}$ membranes. Neutral-gray filters were used to attenuate the light to defined intensities.

After the end of the illumination, the solution was transferred into an Eppendorf tube and kept in the dark on ice. The volume was determined to make sure that no significant evaporation of the solution took place during illumination, which could last up to 60 min. Each experiment was repeated 3-5 times.

\section{Determination of the EnZyme Activity}

Enzyme activity was determined optically by consumption of $\mathrm{NADH}$ in a stoichiometric ratio by the linked pyruvate kinase/ lactate dehydrogenase assay (Schwartz et al., 1971) at $37{ }^{\circ} \mathrm{C}$. Substrate concentrations were chosen to obtain maximum turnover of the ion pumps (in mM: Na,K-ATPase: $100 \mathrm{NaCl}, 10 \mathrm{KCl}, 5$ $\mathrm{MgCl}_{2}, 1.5$ ATP, pH 7.2; SR Ca-ATPase: $0.2 \mathrm{CaCl}_{2}, 50 \mathrm{KCl}$, $2 \mathrm{MgCl}_{2}, 4.5 \mathrm{ATP}, \mathrm{pH}$ 7.2). Experiments were typically performed in triplicate. To compare results from different protein preparations, normalized enzyme activities were calculated by dividing an 
actual activity by that in the presence of rose bengal and before photodynamic modification.

\section{Detection of Partial Reactions with RH421}

Partial reactions of the Na,K-ATPase transport cycle were analyzed by fluorescence measurements in a Perkin-Elmer LS 50B fluorescence spectrophotometer as described recently (Schneeberger \& Apell, 2001). The excitation wavelength was set to $580 \mathrm{~nm}$ and the emission wavelength to $650 \mathrm{~nm}$ (slit width $15 \mathrm{~nm}$ and $20 \mathrm{~nm}$, respectively). Experiments were performed in standard buffer containing $25 \mathrm{~mm}$ histidine, $5 \mathrm{~mm} \mathrm{MgCl}_{2}, 0.5 \mathrm{~mm}$ EDTA, $\mathrm{pH}$ 7.0. $200 \mathrm{~nm}$ RH421 and 9-10 $\mu \mathrm{g} / \mathrm{ml}$ of membrane fragments containing $\mathrm{Na}, \mathrm{K}$-ATPase were added to the thermostated cuvette and equilibrated until a stable fluorescence signal, $F_{0}$, was obtained. Subsequently, substrates were added. The collected data were transferred to and analyzed by a computer. The temperature in the cuvette was maintained at $18{ }^{\circ} \mathrm{C}$. To allow comparison between different titration experiments relative fluorescence changes, $\Delta F /$ $F_{x}=\left(F-F_{\mathrm{x}}\right) / F_{\mathrm{x}}$, were calculated with respect to a reference level $F_{\mathrm{x}}$. Specific fluorescence levels could be assigned to defined states in the pump cycle of the Na,K-ATPase (Heyse et al., 1994).

\section{Results}

Previous work showed that the enzyme activity of the $\mathrm{Na}, \mathrm{K}-\mathrm{ATPase}$ and the amplitude of several partial reactions of the pump cycle are strongly reduced in the presence of free radicals of water radiolysis. An exponential decrease to virtually zero was observed as the applied radiation dose was increased (Hitschke et al., 1994, Mense et al., 1997). Here, corresponding experiments are presented on the inactivation by visible light in the presence of the sensitizer rose bengal.

\section{Inactivation of EnZyme Activity}

The photodynamic inactivation of the Na,K-ATPase was studied in TRIZMA-maleate standard buffer with $1 \mu \mathrm{m}$ rose bengal and $30 \mu \mathrm{g}$ pump protein. $20 \mu \mathrm{l}$ of the solution were filled into a glass capillary and illuminated for variable periods of time at a constant light intensity of $84 \mathrm{~mW} / \mathrm{cm}^{2}$. Aliquots of the illuminated solution were used to determine the remaining enzyme activity. At the light intensity and concentrations of rose bengal and protein chosen, the enzyme activity was typically reduced to about $10 \%$ within $30 \mathrm{~min}$. This holds true in the absence of radical scavengers (see below).

Fig. 1 shows the average of four experiments of the time dependence (which is equivalent to a "lightdose" dependence) of the normalized enzyme activity after illumination. The decrease of enzyme activity (filled circles) in the time range up to 1 hour was found to be in fair agreement with a sum of two exponentials,

$$
A(t) / A(0)=\alpha_{1} \exp \left(-t / \tau_{1}\right)+\alpha_{2} \exp \left(t / \tau_{2}\right),
$$

(with $\alpha_{1}+\alpha_{2}=1$ ). The control experiments indicate that both the presence of the sensitizer and light

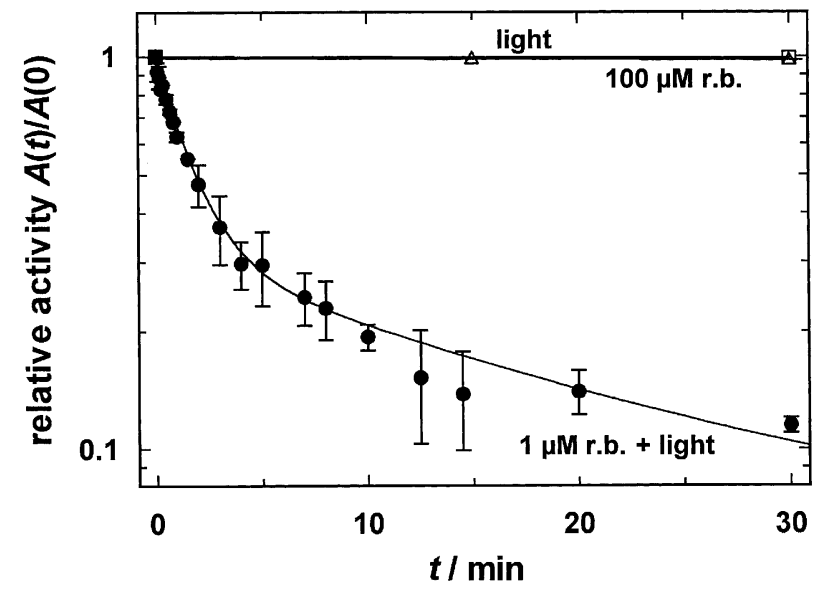

Fig. 1. Inactivation of $\mathrm{Na}, \mathrm{K}-\mathrm{ATPa} e$ induced by illumination of the enzyme with visible light in the presence of $1 \mu \mathrm{M}$ rose bengal (filled circles). The enzyme activity $A(t)$ was normalized to the value, $A(0)$, observed in the presence of rose bengal, before illumination. The light intensity was $84 \mathrm{~mW} / \mathrm{cm}^{2}$. The error bars are standard errors of three or four individual experiments. The time course of the enzyme inactivation was fitted by a sum of two exponentials according to Eq. 1 , with $\tau_{1}=1.59 \mathrm{~min}, \tau_{2}=18.9$ $\min , \alpha_{1}=0.73$ and $\alpha_{2}=0.27$. Controls were performed by incubation with $100 \mu \mathrm{m}$ rose bengal (r.b.) in the dark (empty squares) or by illumination of the enzyme in the absence of rose bengal (triangles).

exposition were required for inactivation (Fig. 1). In addition, no significant changes of the enzyme inactivation were observed if the normal air-saturated solutions were replaced by solutions bubbled with $100 \%$ oxygen (data not shown).

In order to study the role of singlet oxygen for enzyme inactivation, experiments were performed in the presence of $25 \mathrm{~mm}$ imidazole (instead of TRIZMA-maleate), or with $\mathrm{H}_{2} \mathrm{O}$ replaced by $\mathrm{D}_{2} \mathrm{O}$ (Fig. 2 and Table 1). Imidazole (as well as the amino acid histidine, which contains an imidazole ring) is highly reactive towards singlet oxygen (Straight \& Spikes, 1985), and may be considered a model of the physiological scavengers that reduce the life time and, in consequence, the concentration of $\mathrm{O}_{2}^{1} . \mathrm{D}_{2} \mathrm{O}$, on the other hand, increases the life time of singlet oxygen by about a factor of 16 as compared to $\mathrm{H}_{2} \mathrm{O}$ (see Tsai, Godin \& Wand, 1985 or Giulivi et al., 1990, for a compilation of corresponding data). Therefore, the rate of inactivation is expected to decrease in the presence of imidazole, and to increase when experiments are performed in $\mathrm{D}_{2} \mathrm{O}$. This is only correct, however, if inactivation of the enzyme is (at least in part) due to an attack of $\mathrm{O}_{2}^{1}$ from the aqueous phase (see Discussion).

The results of the corresponding experiments for the $\mathrm{Na}, \mathrm{K}-\mathrm{ATPase}$ are in agreement with these arguments and show a substantial modification of the rate of inactivation (Fig. 2A). To demonstrate that this observation is not specific for the Na,K-ATPase but 


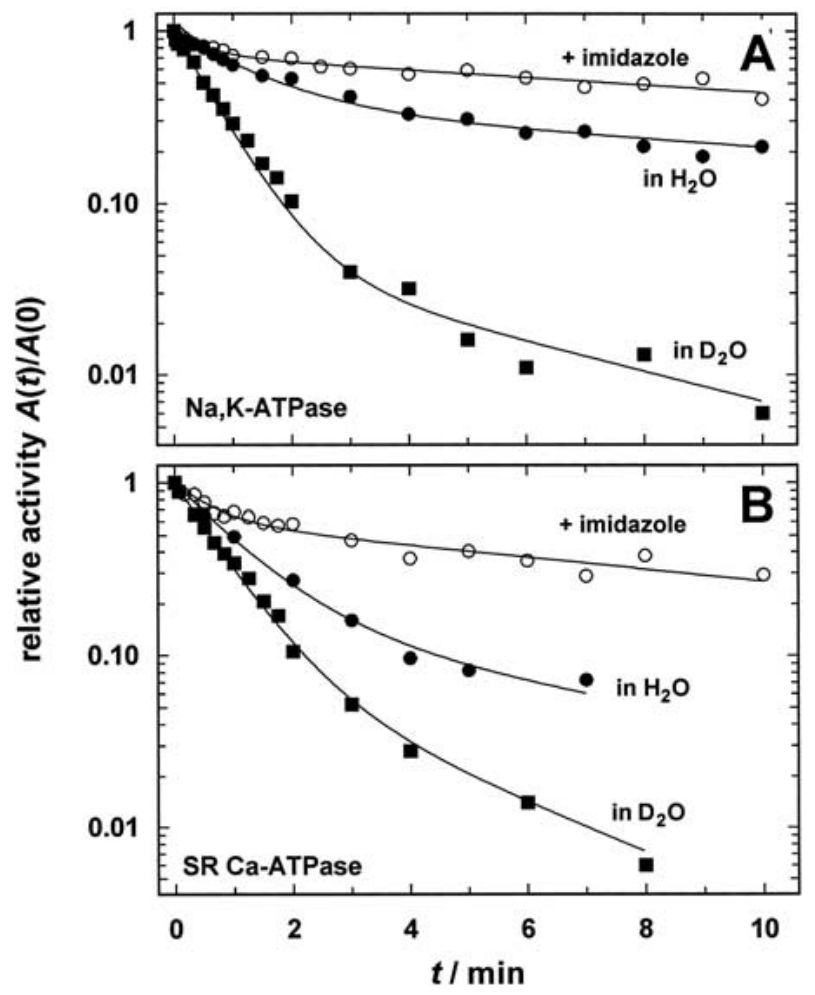

Fig. 2. Inactivation of Na,K-ATPase $(A)$ and SR Ca-ATPase $(B)$ under the experimental conditions of Fig. 1 (filled circles), in the presence of $25 \mathrm{~mm}$ imidazole (empty circles), and with $\mathrm{H}_{2} \mathrm{O}$ replaced by $\mathrm{D}_{2} \mathrm{O}$ (filled squares). As in Fig. 1, the decay of the enzyme activity was found to agree with Eq. 1 (solid lines). For the sake of clarity only one set of experiments of each buffer condition is shown. For summary of kinetic parameters, see Table 1.

is a more general property of P-type ATPases, the experiments were repeated with SR Ca-ATPase (Fig. 2B). The main effect of $\mathrm{D}_{2} \mathrm{O}$ is an enhancement of the amplitude $\alpha_{1}$ of the fast initial decay at cost of the second amplitude $\alpha_{2}$. For Na,K-ATPase, $\alpha_{1}$ increases from 0.64 ( 0.28 in the presence of imidazole) to 0.93 . The same holds - though to a somewhat smaller extent-for the SR Ca-ATPase (Table 1). This indicates that an important part (at least $90 \%$ in $\mathrm{D}_{2} \mathrm{O}$ ) of enzyme inactivation is due to singlet oxygen attack from the aqueous phase, since it is the concentration of this species that is affected by $\mathrm{D}_{2} \mathrm{O}$ and by imidazole.

At comparatively low $\mathrm{O}_{2}^{1}$ concentrations in water, the importance of the slow component of enzyme inactivation was found to be enhanced at cost of the fast process (Table 1). This indicates that the two exponentials, which represent the decay of activity, reflect two independent inactivation pathways. To exclude that the slow inactivation component is caused by oxygen depletion, control experiments were performed in oxygen-saturated buffer. The resulting inactivation curves were found to be virtually identical to those in normal air.
The experiments in the presence of imidazole showed only partial enzyme inactivation within an illumination time of $10 \mathrm{~min}$, as shown in Fig. 2. Even after $30 \mathrm{~min}$ of illumination, a residual activity of about $30 \%$ was observed (Fig. $3 A$ ). It was, however, reduced to the $1 \%$ level, if the sensitizer concentration was enhanced from $1 \mu \mathrm{M}$ to $100 \mu \mathrm{M}$ (Fig. 3A). Therefore, in order to analyze the slow part of the inactivation process over a broader range, the subsequent experiments were performed using $100 \mu \mathrm{M}$ rose bengal in the presence of $25 \mathrm{~mm}$ imidazole.

Figure $3 B$ illustrates the dose-rate dependence of the inactivation process of the $\mathrm{Na}, \mathrm{K}$-ATPase. (We use the term "dose rate" instead of "fluence rate" to comply with the literature on the effects of ionizing radiation.) The dose rate was varied by attenuation of the light intensity of $84 \mathrm{~mW} / \mathrm{cm}^{2}$ by neutral-gray glass filters to lower values. At constant values of the light dose (which is defined as the product of light intensity and time of illumination), the figure shows increasingly smaller values of the enzyme activity as the dose rate is reduced. Such a behavior is defined as an inverse dose rate behavior and is typical for radical chain mechanisms such as lipid peroxidation (see Discussion). The same behavior was also observed for the SR Ca-ATPase (data not shown). The inverse dose rate behavior was, however, only found for the slow phase of inactivation, while for the fast initial phase enzyme inactivation did not depend on the dose rate (see inset of Fig. $3 B$ ).

In order to estimate possible effects of rose bengal bleaching during longer times of irradiation, control experiments were performed in which $100 \mu \mathrm{M}$ of the photosensitizer were illuminated in standard buffer with imidazole for time intervals up to $30 \mathrm{~min}$. No significant bleaching effects were observed, as determined from absorption spectra of irradiated rose bengal solutions (data not shown).

The influence of the lipid environment was studied by enzyme inactivation of $\mathrm{Na}, \mathrm{K}$-ATPase or SR Ca-ATPase in reconstituted vesicles. The saturated diphytanoyllecithin (DPhPC) or the unsaturated dioleoyllecithin (DOPC) were chosen to identify contributions of lipid peroxidation, which is strongly enhanced in unsaturated lipids.

Similar patterns were found when the reconstituted ion pumps were compared with the native membrane preparations. When the proteoliposomes were prepared in TRIZMA maleate standard buffer (i.e., in the absence of the singlet oxygen scavenger imidazole) a largely monoexponential enzyme inactivation was observed (i.e., $\alpha_{2}<10 \%$, data not shown). In preparations that were prepared in the presence of imidazole, a biphasic enzyme inactivation was found $\left(\alpha_{1} / \alpha_{2} \approx 2 / 3\right.$, see Fig. 4$)$.

Surprisingly, only comparatively small differences of photodynamic enzyme inactivation were found for ion pumps reconstituted in saturated and 
Table 1. Comparison of enzyme inactivation for the Na,K-ATPase and the SR Ca-ATPase in buffers with different life times of singlet oxygen (see text). The parameters listed are results of least-square fits of Eq. 1 to the data in Fig. 2.

\begin{tabular}{|c|c|c|c|c|c|}
\hline Enzyme & Buffer & $\tau_{1} / \min$ & $\tau_{2} / \min$ & $\alpha_{1}$ & $\alpha_{2}=1-\alpha_{1}$ \\
\hline \multirow[t]{3}{*}{ Na,K-ATPase } & $\mathrm{D}_{2} \mathrm{O}$ & $0.73 \pm 0.02$ & $5.0 \pm 2.4$ & $0.93 \pm 0.02$ & $0.07 \pm 0.02$ \\
\hline & TRIZMA & $1.38 \pm 0.12$ & $18.9 \pm 1.0$ & $0.64 \pm 0.02$ & $0.36 \pm 0.02$ \\
\hline & imidazole & $0.71 \pm 0.20$ & $20.3 \pm 2.6$ & $0.28 \pm 0.03$ & $0.72 \pm 0.03$ \\
\hline \multirow[t]{3}{*}{ Ca-ATPase } & $\mathrm{D}_{2} \mathrm{O}$ & $0.77 \pm 0.04$ & $5.0 \pm 3.0$ & $0.91 \pm 0.03$ & $0.09 \pm 0.03$ \\
\hline & TRIZMA & $1.08 \pm 0.16$ & $6.6 \pm 4.1$ & $0.83 \pm 0.11$ & $0.17 \pm 0.11$ \\
\hline & imidazole & $1.11 \pm 0.05$ & $22.2 \pm 6.8$ & $0.63 \pm 0.06$ & $0.47 \pm 0.06$ \\
\hline
\end{tabular}
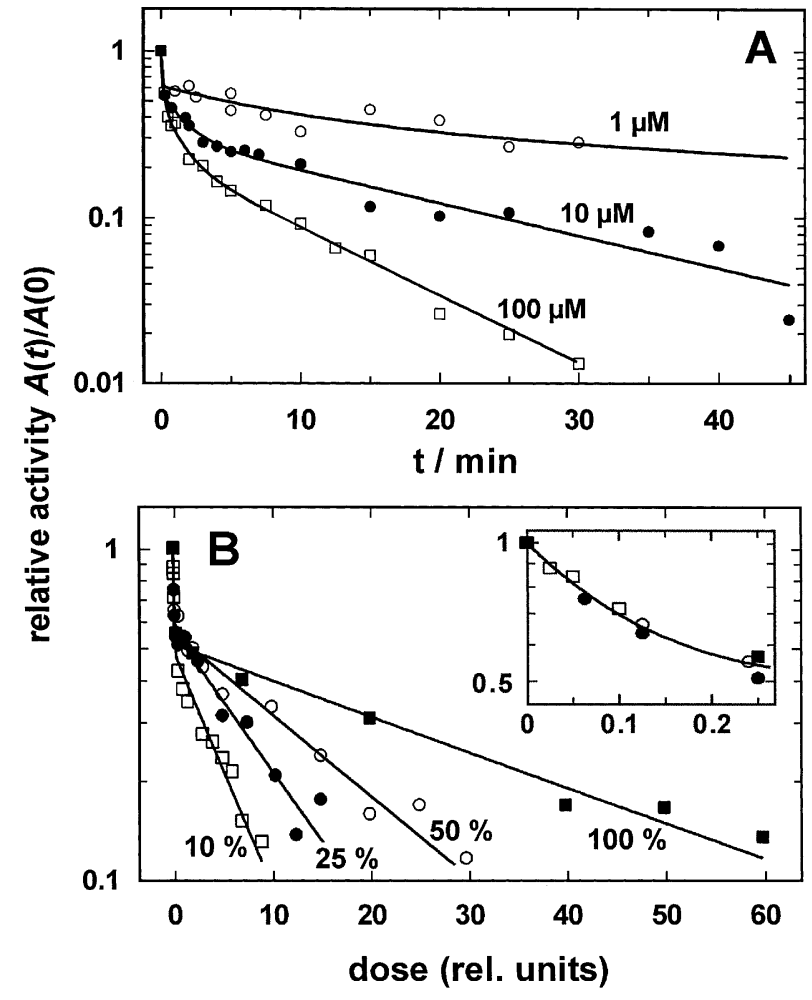

Fig. 3. Effects of photosensitizer concentration and dose rate on the inactivation of the Na,K-ATPase. $(A)$ Experiments comparable to that in Fig. 1, however, in the presence of $25 \mathrm{~mm}$. imidazole at rose bengal concentrations of $1 \mu \mathrm{M}, 10 \mu \mathrm{M}$, and $100 \mu \mathrm{M}$. The fit parameters according to Eq. 1 were $\left(\tau_{1}, \tau_{2}, \alpha_{1}\right):(1 \mu \mathrm{M}) 0.41 \mathrm{~min}, 55$

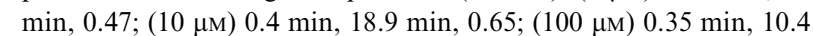
min, 0.75. (B) Experiments with Na,K-ATPase in the presence of $100 \mu \mathrm{M}$ rose bengal were performed at different dose rates by reduction of the light intensity applied: $100 \%, 50 \%, 25 \%$, and $10 \%$ (maximum intensity $84 \mathrm{~mW} / \mathrm{cm}^{2}$ ). The remaining enzyme activity was plotted against the applied dose (in arbitrary units), which is proportional to the product of light intensity and duration of illumination. Single data sets are shown in each panel (Averaging of data sets would lead to standard errors as shown in Fig. 1). The fit parameters according to Eq.(1) were $\left(\tau_{1}, \tau_{2}, \alpha_{1}\right)$ : (100\%) $0.10 \mathrm{~min}$, $42.2 \mathrm{~min}, 0.47,(50 \%) 0.07 \mathrm{~min}, 18.5 \mathrm{~min}, 0.43,(25 \%) 0.7 \mathrm{~min}, 10.8$ $\min , 0.47,(10 \%) 0.75 \mathrm{~min}, 6.37 \mathrm{~min}, 0.49$. The inset shows the fast component of enzyme inactivation with high time resolution to illustrate that the underlying process is dose-rate independent.

unsaturated lipids. This is shown in Fig. 4 for Na, KATPase-containing vesicles in imidazole buffer,

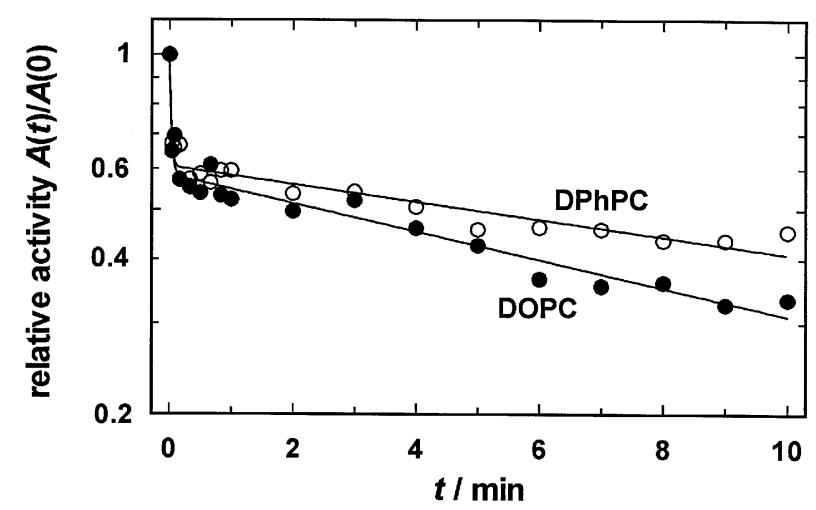

Fig. 4. Inactivation of $\mathrm{Na}, \mathrm{K}-\mathrm{ATPa} e$ reconstituted in lipid vesicles formed from either unsaturated dioleoyllecithin (filled circles) or saturated diphytanoyllecithin (empty circles). The Na,K-ATPasecontaining vesicles were illuminated in the presence of $100 \mu \mathrm{M}$ rose bengal and $25 \mathrm{~mm}$ imidazole at a light intensity of $84 \mathrm{~mW} / \mathrm{cm}^{2}$. The data represent a single set of data for each experimental condition. (For parameters, see text.)

where the effects of the lipid phase are expected to be most pronounced. While the fast inactivation component was virtually identical for both lipids $\left(\tau_{1}=0.03 \pm 0.007 \mathrm{~min}\right)$, the time constant of the slow component was smaller only by a factor of 1.7 for the unsaturated lipid $\left(\tau_{2}(\mathrm{DOPC})=15.5 \pm 1.6\right.$ min $\left.\quad v s . \quad \tau_{2}(\mathrm{DPhPC})=25 \pm 2.9 \quad \mathrm{~min}\right)$, while the amplitudes were largely identical $\left(\alpha_{1}\right.$ (DOPC) $\left.=0.4 \pm 0.01, \quad \alpha_{1}(\mathrm{DPhPC})=0.39 \pm 0.01\right)$

(see Discussion).

\section{Tryptophane Fluorescence}

The $\mathrm{Na}, \mathrm{K}$-ATPase is an $\alpha \beta$ protomer containing 16 tryptophane residues, 12 for the $\alpha$ subunit and 4 for the $\beta$ subunit. The steady-state fluorescence emission spectrum of the Na,K-ATPase exhibits a maximum at $340-342 \mathrm{~nm}$. In order to study possible photodynamic modifications of these aromatic amino-acid side chains, membrane preparations were illuminated under standard conditions (without imidazole) in the presence of $100 \mu \mathrm{M}$ rose bengal for $40 \mathrm{~min}$. After this treatment no enzyme activity was left. When the fluorescence emission spectra were compared before and after illumination under otherwise identical 
conditions, only a small difference of $3.5 \%$ was found in the emission maximum at $342 \mathrm{~nm}$ (excitation at $280 \mathrm{~nm}$ ). This result indicates that the tryptophane side chains are not essential targets of photomodification.

\section{Effects on Partial Reactions of the Na,K-ATPase}

The experiments on the partial reactions of the pump cycle were intended to provide a more detailed picture of the inactivation mechanism. The fluorescence of the electrochromic styryl dye RH421 allows the detection of substrate-dependent, electrogenic transitions within the pump cycle. In brief, substrate-induced transitions (i.e., the partial reactions) that move electric charge in and out of the membrane domain of the transport protein cause changes of the fluorescence intensity of the dye (Pedersen et al., 2001). This method was repeatedly used in order to gain insight into the transport kinetics of the $\mathrm{Na}, \mathrm{K}$ ATPase (Heyse et al., 1994, Apell, 2003) and of the SR Ca-ATPase (Peinelt \& Apell, 2002), and to study the effects of free radicals of water radiolysis on the Na,K-ATPase (Mense et al., 1997).

A typical experiment as described in Methods is shown in Fig. $5 B$. The sensitizer was added to the membrane fragments containing TRIZMA maleate buffer before illumination to obtain a concentration of $1 \mu \mathrm{M}$. After the photodynamic treatment, the membrane preparation was transferred into the cuvette in the dark and diluted to obtain the concentration mentioned above. In the experiments with the scavenger imidazole, TRIZMA maleate was replaced by imidazole, and the rose bengal concentration was $100 \mu \mathrm{M}$. All other experimental conditions were identical.

Figure $5 A$ shows the Post-Albers cycle of ion transport by the Na,K-ATPase to illustrate the substrate-induced partial reactions. At the initial buffer conditions (i.e., without $\mathrm{Na}^{+}$and $\mathrm{K}^{+}$ions, see above), the enzyme is stabilized in the conformation $E_{1}$, which is characterized by the fluorescence level $F_{0}$. Subsequent additions initiate partial reactions into new steady states of the enzyme with different characteristic fluorescence levels (see also Fig. 5B): addition of $50 \mathrm{~mm} \mathrm{NaCl}$ produces the state $\mathrm{Na}_{3} \mathrm{E}_{1}$ (characterized by the lower fluorescence level, $F_{\mathrm{NaCl}}$ ). After addition of $500 \mu \mathrm{M}$ ATP, the ion pumps are transferred into state $\mathrm{P}-\mathrm{E}_{2}$ (with the enhanced fluo-

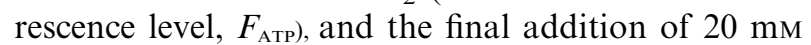
$\mathrm{KC} 1$ leads preferentially to state $\mathrm{E}_{2}\left(\mathrm{~K}_{2}\right)$ with two $\mathrm{K}^{+}$ ions bound to the enzyme in conformation $\mathrm{E}_{2}$ (reduced fluorescence level, $\left.F_{\mathrm{KCl}}\right)$.

The fluorescence responses obtained from enzyme in $\mathrm{D}_{2} \mathrm{O}$ standard buffer with TRIZMA maleate and with $1 \mu \mathrm{M}$ rose bengal is shown in Fig. $5 B$ before illumination, and in Fig. $5 C$ after 40 minutes of photodynamic treatment of the membrane prepara-
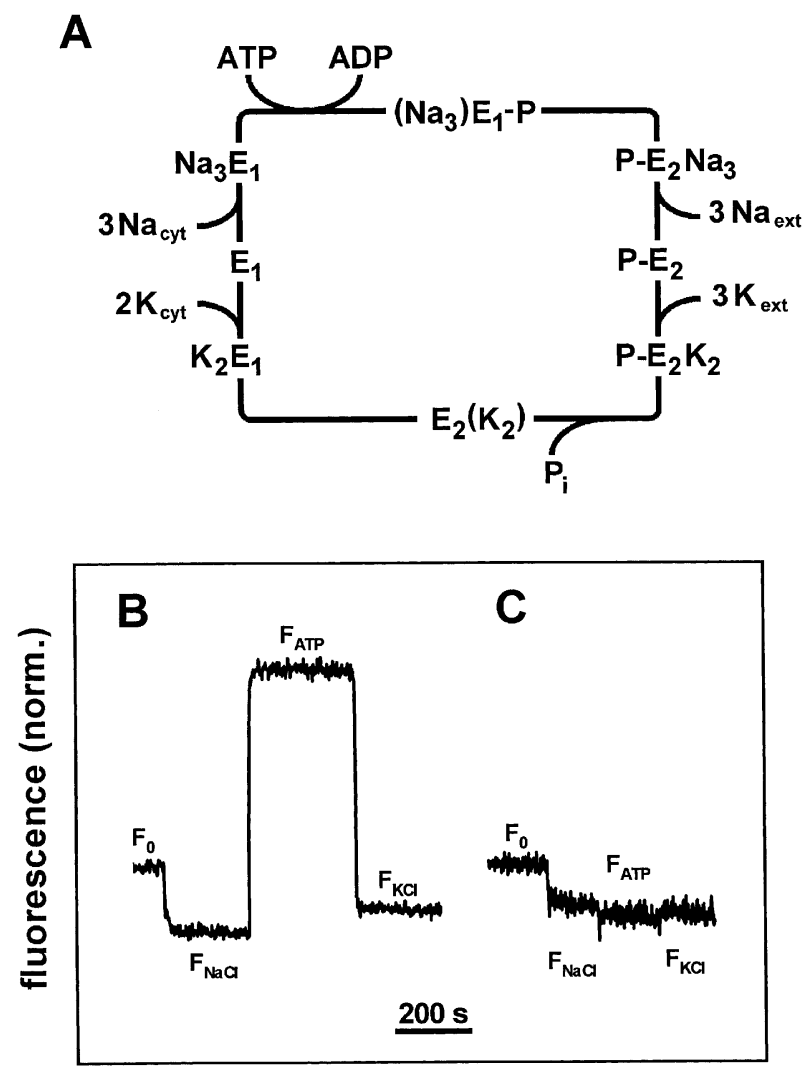

Fig. 5. Photodynamic effects on the partial reactions of the Na,KATPase detected by fluorescence experiments. The fluorescence of a cuvette containing $25 \mathrm{~mm}$ histidine $(\mathrm{pH} 7), 1 \mathrm{~mm}$ EDTA, $5 \mathrm{~mm}$ $\mathrm{MgCl}_{2}, 200 \mathrm{~nm} \mathrm{RH421,} 5 \mathrm{~nm}$ rose bengal, and $3 \mu \mathrm{g} / \mathrm{ml} \mathrm{Na}, \mathrm{K}-$ ATPase was studied as a function of time. $(A)$ Post-Albers cycle of the Na,K-ATPase describing the ion transport processes. The electrochromic styryl dye RH421 monitors substrate-dependent, electrogenic transitions into new steady states: $\mathrm{E}_{1} \rightarrow \mathrm{Na}_{3} \mathrm{E}_{1}$ $\left(F_{\mathrm{NaCl}}\right), \mathrm{Na}_{3} \mathrm{E}_{1} \rightarrow \mathrm{P}-\mathrm{E}_{2}\left(F_{\mathrm{ATP}}\right), \mathrm{P}-\mathrm{E}_{2} \rightarrow \mathrm{E}_{2}\left(\mathrm{~K}_{2}\right)\left(F_{\mathrm{KCl}}\right)$, which are induced by addition of $\mathrm{NaCl}$ to a final concentration of $50 \mathrm{~mm}$, by addition of ATP to a final concentration of $500 \mu \mathrm{M}$, and by addition of $\mathrm{KCl}$ to a final concentration of $20 \mathrm{~mm}$, respectively. $(B)$ The experiment was performed before illumination of the enzyme preparation in the presence of $1 \mu \mathrm{M}$ rose bengal in $\mathrm{D}_{2} \mathrm{O}$. (C) Respective experiment performed after $40 \mathrm{~min}$ of illumination. The fluorescence intensities were normalized to the initial level, $F_{0}$, i.e., $\left(F(\mathrm{t})-F_{0}\right) / F_{0}$ was plotted to allow a direct comparison of both experiments.

tion (at $84 \mathrm{~mW} / \mathrm{cm}^{2}$ ). Comparison of Figs. $5 B$ and $5 C$ indicates that the amplitude of the first fluorescence response (which represents cytoplasmic $\mathrm{Na}^{+}$binding) was reduced after irradiation to about $60 \%$ of the initial value and the amplitudes of the two subsequent partial reactions are virtually abolished. Experiments with imidazole or TRIZMA maleate as buffer in water (instead of $\mathrm{D}_{2} \mathrm{O}$ ) showed after $40 \mathrm{~min}$ of illumination only incomplete suppression of the ATPinduced fluorescence response (see below).

To determine the dose dependence of the amplitudes of the substrate-induced partial reactions, the time of illumination was varied between 0 and 40 


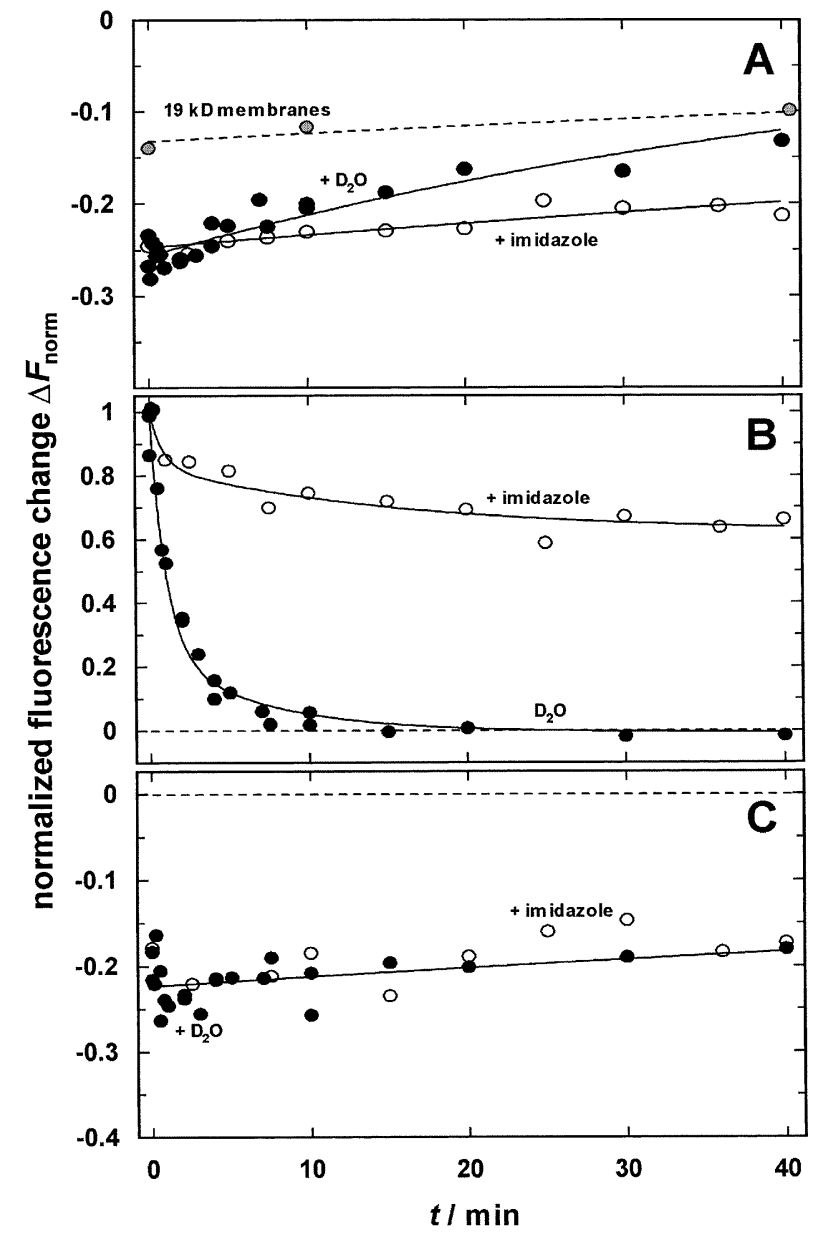

Fig. 6. Dependence of the amplitude of fluorescence changes, $\Delta F_{\text {norm, }}$ ( $c f$. Fig. 5) on illumination time. Two different buffer conditions were chosen: standard buffer with $\mathrm{D}_{2} \mathrm{O}$ instead of $\mathrm{H}_{2} \mathrm{O}$ (filled circles) or \pm standard buffer $+25 \mathrm{~mm}$ imidazole (empty circles). Here, the fluorescence amplitudes are normalized to a reference level, $F_{\mathrm{x}}(\mathrm{x}=0$ or $\mathrm{NaCl})$ before addition of a substrate. Fluorescence changes were induced $(A)$ by addition of $\mathrm{NaCl}$ to native enzyme preparations and to $19-\mathrm{kDa}$ membranes in standard buffer $+25 \mathrm{~mm}$ imidazole (hatched circles). $\Delta F_{\text {norm }}=\left(F(\mathrm{t})-F_{0}\right) / F_{0}$, $(B)$ by addition of ATP, $\Delta F_{\text {norm }}=\left(F(\mathrm{t})-F_{\mathrm{NaCl}}\right) / F_{\mathrm{NaCl}}$, and $(C)$ by addition of $\mathrm{KCl}, \Delta F_{\text {norm }}=\left(F(\mathrm{t})-F_{0}\right) / F_{0}$. (For its parameter, see text.)

minutes. Fig. 6 shows the development of the three substrate-dependent fluorescence changes. The amplitudes are normalized to the fluorescence level, $F_{\mathrm{x}}$, before addition of $\mathrm{Na}^{+}$(Fig. $6 A$ and $6 C$ ) or ATP $($ Fig. $6 B): \Delta F_{\text {norm }}=\left(F(t)-F_{\mathrm{x}}\right) / F_{\mathrm{x}} \quad(\mathrm{x}=0, \quad \mathrm{NaCl}$, respectively). Different series were performed in the presence of $\mathrm{D}_{2} \mathrm{O}$ with $1 \mu \mathrm{M}$ rose bengal, in the presence of $25 \mathrm{~mm}$ imidazole and $100 \mu \mathrm{m}$ rose bengal, as well as a few control experiments with $19 \mathrm{kDa}$ membranes, which contain only the transmembrane segments of the Na,K-ATPase.

The $\mathrm{Na}^{+}$-induced fluorescence decrease is caused by electrogenic binding of the third $\mathrm{Na}^{+}$ion to its site in the membrane domain of the protein by the partial reaction $\mathrm{Na}_{2} \mathrm{E}_{1}+\mathrm{Na}^{+} \rightarrow \mathrm{Na}_{3} \mathrm{E}_{1}$ (Apell \& Karlish, 2001). In $\mathrm{D}_{2} \mathrm{O}$ a monoexponential reduction of the (negative) amplitude of this process was found with an estimated time constant of the order of $1 \mathrm{~h}$ (Fig. 6A). There was no contribution of a fast component as it was observed in the case of enzyme inactivation (Fig. 2A). A corresponding result was found for buffer containing $25 \mathrm{~mm}$ imidazole. The even slower reduction of the fluorescence decrease may be easily explained by the scavenger-induced decreased concentration of singlet oxygen.

In contrast to $\mathrm{Na}^{+}$-binding, the loss of the ATPinduced fluorescence change, $\mathrm{Na}_{3} \mathrm{E}_{1}+\mathrm{ATP} \rightarrow \mathrm{P}-\mathrm{E}_{2}$ $+3 \mathrm{Na}^{+}{ }_{\text {ext }}+$ ADP, shows a biexponential behavior. The data obtained in $\mathrm{D}_{2} \mathrm{O}$ could be fitted by Eq. (1), similar to the decay of enzyme activity by photodynamic inactivation in $\mathrm{D}_{2} \mathrm{O}$ (compare Figs. $2 A$ and $6 B)$, with $\tau_{1}=0.85 \mathrm{~min}$ and $\tau_{2}=5.9 \mathrm{~min}$. A small difference was observed in the contribution of the fast component, which was $85 \%$ here, but about $95 \%$ in the case of enzyme activity. When the experiments were performed in buffer containing $25 \mathrm{~mm}$ imidazole, the fast component, $\tau_{1}<1 \mathrm{~min}$, had an amplitude of $\sim 15 \%$, a second component with $\tau_{2}=15.6$ min contributed with $21 \%$, and an extremely slow process ( $>500 \mathrm{~min}$ ) has to account for the remaining amplitude. With exception of the latter process this behavior agrees well with the effect of the inactivation of the overall enzyme activity in buffer containing $\mathrm{D}_{2} \mathrm{O}$ or imidazole (Table 1).

The third, $\mathrm{K}^{+}$-induced partial reaction, $\mathrm{P}-\mathrm{E}_{2}+2$ $\mathrm{K}^{+} \rightarrow \mathrm{E}_{2}\left(\mathrm{~K}_{2}\right)+\mathrm{P}_{\mathrm{i}}$, is accompanied in the active enzyme by a large fluorescence decrease (Fig. $5 B$ ) due to electrogenic $\mathrm{K}^{+}$-binding to state $\mathrm{P}-\mathrm{E}_{2}$ (Bühler \& Apell, 1995). The photodynamically induced amplitude reduction of this process is mainly produced by the decay of the preceding ATP-induced effect in both buffers, containing either $\mathrm{D}_{2} \mathrm{O}$ or imidazole. When the $\mathrm{K}^{+}$-stabilized fluorescence level was compared with the initial fluorescence level $F_{0}$ (as shown in Fig. $6 C$ ), only a very slow reduction of the fluorescence level, $\Delta F_{\text {norm, }}$, was found (time constant $\tau_{1}>1$ h). Fig. $6 A-C$ indicates that both membranerelated processes, i.e., $\mathrm{Na}^{+}-$and $\mathrm{K}^{+}$-binding, were less affected by the photodynamic modification of the protein than the ATP-induced effect.

A central issue of the inactivation mechanism (to be discussed in detail below) deals with the importance of the cytoplasmic and of the membrane domains of the Na,K-ATPase for enzyme inactivation. Therefore, photodynamic modification of $\mathrm{Na}^{+}$ binding to the native enzyme was compared with that to so-called $19 \mathrm{kDa}$ membranes, in which the cytoplasmic domains are removed by specific tryptic cleavage (Capasso et al., 1992). The remaining protein torso still contains active ion-binding sites (Schwappach et al., 1994). These experiments had to be performed in imidazole-containing standard buffer 
(due to the preparation procedure of the $19 \mathrm{kDa}$ membranes) with $100 \mu \mathrm{M}$ rose bengal, and at $0^{\circ} \mathrm{C}$, to prevent a well-known thermal inactivation of the membrane domain at room temperature (Schwappach et al., 1994). The results (from a single set of control experiments) are included as control in Fig. 6A. The smaller fluorescence response on $\mathrm{Na}^{+}$ binding, $\Delta F_{\text {norm }}$, as observed already before irradiation, is in agreement with published data. Comparable to the case of $\mathrm{Na}^{+}$binding to the native enzyme, the fluorescence response, $\Delta F_{\text {norm }}$, of the $19 \mathrm{kDa}$ membranes showed a slow decay over a time range of $40 \mathrm{~min}$ in the same way as in the experiments with native enzyme in imidazole buffer (Fig. 6A).

\section{Discussion}

The photosensitized oxidation of enzymes, the procedure applied in this study, is a complex phenomenon that is usually discussed on the basis of Type I and Type II reactions (Foote, 1976, Straight \& Spikes, 1985). There is, however, general agreement that the formation of highly reactive singlet oxygen, $\mathrm{O}_{2}^{1}$, formed by a Type II reaction, is of central importance for many photosensitized reactions. This is also true for the inactivation of the two ion pumps considered here. Addition of the singlet oxygen scavenger imidazole gives rise to a substantial decrease of the rate of enzyme inactivation (Fig. 2), as was first shown by Hess and coworkers for histidine (Kukreja \& Hess, 1992, Vinnikova et al., 1992). On the other hand, an enhancement of the life time of $\mathrm{O}_{2}^{1}$, obtained by using $\mathrm{D}_{2} \mathrm{O}$ instead of $\mathrm{H}_{2} \mathrm{O}$, strongly increases the rate of photooxidation (Fig. 2).

The photosensitized decay of the activity of both P-type ATPases is characterized by two components, a fast component and a slow component. In the absence of scavengers (and especially in the presence of $\left.\mathrm{D}_{2} \mathrm{O}\right)$, the fast component is the predominant one (Fig. 2). In the presence of the $\mathrm{O}_{2}^{1}$ scavenger imidazole, the importance of the slow component is found to be enhanced (Figs. 2, 4 and 6). Since imidazole is a water-soluble compound, the reduction of the fast inactivation component points to a photomodification of the cytoplasmic part of the ion pumps, which protrudes 5-6 nm out of the membrane into the aqueous phase (see Fig. $7 \mathrm{~A}$ ), while the concomitant increase of the slow component seems to indicate enzyme inactivation via modification of the membrane domain.

The following arguments support the assumption of two different pathways of photodynamic enzyme inactivation:

A close correspondence between the decay of the ATP-induced partial reaction and the decay of the enzyme activity was observed. In both cases a biexponential behavior was found. Obviously, the ATP- induced partial reaction contains an essential step that controls enzyme activity. When enzyme activity is measured, the pump runs through the whole cycle (Fig. 5A). The ATP-induced partial reaction, on the other hand, includes only ATP-binding, enzyme phosphorylation, the conformational transition $\mathrm{E}_{1}$ to $\mathrm{E}_{2}$, and release of the $\mathrm{Na}^{+}$ions. The first two processes are associated with the cytoplasmic domains of the two ion pumps (see Fig. 7) and include a specific interaction of the $\mathrm{N}, \mathrm{P}$ and $\mathrm{A}$ domains, which form the cytoplasmic domain (Toyoshima \& Nomura, 2002). The conformational transition comprises the whole protein structure, and ion release is related to the membrane domain (Apell \& Karlish, 2001).

In the presence of $\mathrm{D}_{2} \mathrm{O}$, when the concentration of singlet oxygen is pronounced, the ATP-induced partial reaction, as well as the overall enzyme activity, are reduced within $10 \mathrm{~min}$ to less than $3 \%$. This observation points to a mechanism that inactivates the ion pump at a reaction step that has to be part of the $\mathrm{Na}^{+}$-translocating half of the pump cycle (Fig. 5A). In experiments performed in the presence of $25 \mathrm{~mm}$ imidazole, the concentration of singlet oxygen was significantly reduced so that the contribution of other reactive species became effective. Under this condition the fast inactivation process was reduced to $28 \%$ in the case of the enzyme activity and to $15 \%$ in the case of the ATP-induced partial reaction. The slow process abolished the enzyme activity with a time constant of $20 \mathrm{~min}$ in the presence of $100 \mu \mathrm{M}$ rose bengal, while in the ATP-induced partial reaction the slow component (time constant of $\sim 16 \mathrm{~min}$ ) was reduced to approximately $60 \%$ of the initial fluorescence amplitude.

In the presence of imidazole, the enzyme activity was reduced to less than $1 \%$ after 30 min of illumination (Fig. $3 A$ ), while still $60 \%$ of the fluorescence increase were observed (Fig. 6B). This discrepancy provides some insight into the effect of the predominant reactive species when singlet oxygen is quenched. The high fluorescence level reflects a (still) significantly high population of the state P-E2. Obviously, the ion pump is able to reach this conformation despite the inhibition of the enzyme turnover and, therefore, a reaction step subsequent to the ATP-induced partial reaction has to be disabled by the predominant reactive species in the presence of imidazole. A possibly inhibited reaction step is the conformation transition back to $\mathrm{E}_{1}$. From these observations in the presence and absence of imidazole it is obvious that different steps of the ion pump (and therefore different targets in the protein) are affected, dependent on the principal reactive species present during illumination.

$\mathrm{Na}^{+}$and $\mathrm{K}^{+}$binding showed no significant deviation from a monoexponential inactivation behavior. The corresponding time constants were even larger than that of the slow time constant of 

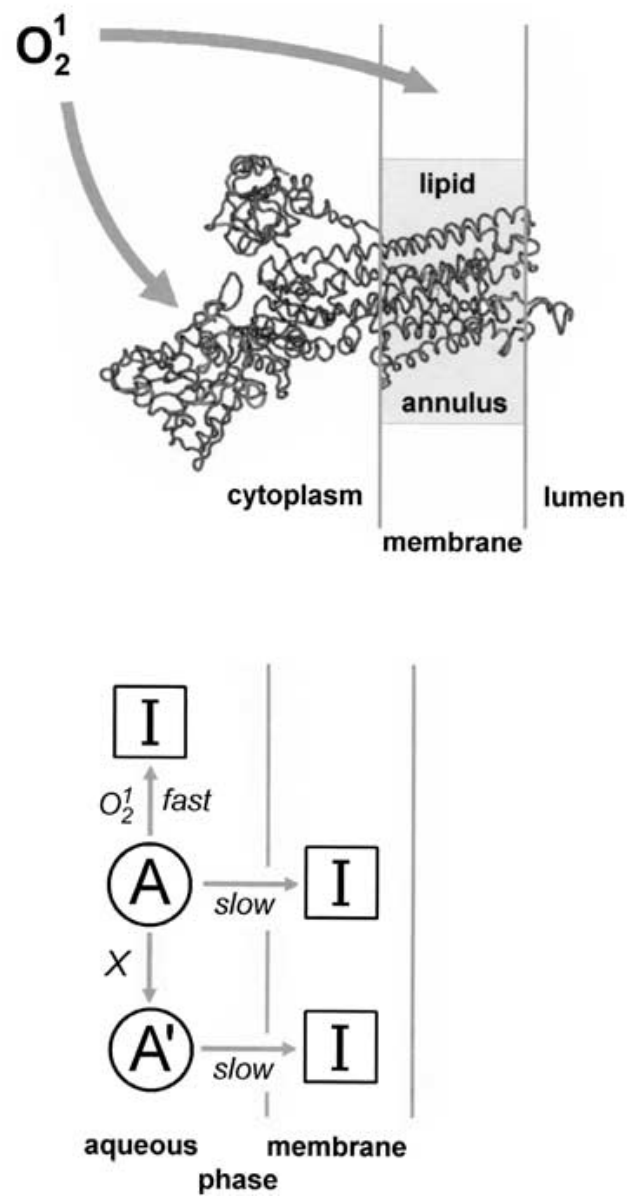

Fig. 7. (A) Tentative model of the photosensitized inactivation of the Na,K-ATPase and the SR Ca-ATPase by rose bengal. Inactivation of enzyme activity is assumed to proceed by (at least) two independent pathways: fast inactivation by reaction of $\mathrm{O}_{2}^{1}$ with the cytoplasmic part of the enzymes and slow inactivation via the membrane phase (e.g., by products of lipid peroxidation). (B) Proposal of a reaction scheme to describe the biexponential inactivation of the enzyme. Species A and $\mathrm{A}^{\prime}$ represent active forms of the enzyme, "I" represents inactive forms, which may differ in their modifications.

enzyme inactivation. The difference in the $\mathrm{Na}^{+}$-induced partial reaction observed in the presence and absence of imidazole (Fig. 6A) may be caused by the different singlet oxygen concentration.

Ion binding is related to the membrane domain of the Na,K-ATPase. This can be concluded also from the experiments with $19 \mathrm{kDa}$ membranes, which showed the same slow time constant of inactivation found for the $\mathrm{Na}^{+}$binding to the native enzyme although in $19 \mathrm{kDa}$ membranes only the membrane domain of $\mathrm{Na}, \mathrm{K}$-ATPase is present (Capasso et al., 1992). In conclusion, the slow inactivation process is thought to be associated with the membrane domain.

The cytoplasmic domains of the Na,K-ATPase seem to be the target for the fast inactivation process. This is supported by the large amplitude of the fast inactivation process (observed by the loss of the fluorescence change of the ATP-induced partial reaction as well as by the decay of the enzyme activity) in combination with the localization of ATP binding and enzyme phosphorylation in the cytoplasmic domains, and with the dependence of the fast process on the aqueous $\mathrm{O}_{2}^{1}$ concentration (Fig. 2).

Further support for the existence of (at least) two different inactivation processes is provided by the dose rate dependence of enzyme inactivation illustrated in Fig. $3 B$. The slow component shows an inverse dose-rate behavior with small dose rates being more effective than high dose rates. No influence of the dose rate was observed for the fast component (inset in Fig. 3). The inverse dose rate effect is typical for radical chain mechanisms (Stark, 1991). This phenomenon suggests an involvement of lipid peroxidation (i.e., an indirect inactivation mechanism), since, to our knowledge, no inverse dose-rate effect has been observed for proteins so far. For cytosolic creatine kinase, a lipid-free protein, no dose rate dependence was observed at X-ray-induced inactivation studies. Addition of lipids was found to induce an inverse dose-rate behavior in this case (Koufen, Brdiczka \& Stark, 2000). Therefore, observation of an inverse dose-rate behavior in the inactivation of both ion pumps might indicate that the slower inactivation component is due to the interaction of the enzyme with reactive products of lipid peroxidation such as malondialdehyde or 4-hydroxynonenal. Direct evidence for the possibility of an inhibition of the $\mathrm{Na}, \mathrm{K}-\mathrm{ATPase}$ by 4-hydroxynonenal has been provided by Siems et al. (1996).

Inverse dose-rate effects, however, may be generated also by oxygen depletion at high dose rates (Veenhuizen \& Stewart, 1995), and have been observed at a number of different photodynamic reactions such as photooxidation of histidine or glutathione (Moor et al., 1997), where the authors excluded oxygen depletion. Oxygen depletion is also unlikely in the experiments presented here, since the shape of the inactivation curves was found to be virtually identical under oxygen-saturated conditions and in normal air.

To study the influence of photosensitized lipid peroxidation on enzyme inactivation, experiments were performed with $\mathrm{Na}, \mathrm{K}$-ATPase reconstituted in lipid vesicles of different oxidizability. The extent of lipid peroxidation is known to be strongly dependent on the degree of unsaturation of the fatty acid residues. Therefore, variation of the lipid should affect in principle the relative importance of the fast and slow inactivation components. However, only a comparatively small change (at the limit of experimental significance) of the time constant of the second inactivation component was observed. For vesicles formed from dioleoyllecithin (with one double bond per fatty acid residue) it was about a factor of two 
smaller as compared with diphytanoyllecithin (with completely saturated fatty acid residues) (Fig. 4). A potential reason for the small effect of the saturated and unsaturated lipids is the presence of a significant amount of native lipids $(\sim 7 \%)$ in the vesicles after the reconstitution procedure. During the solubilization of the membrane preparation with cholate (Apell et al., 1985), the protein has to be surrounded by several layers of lipids, which avoid irreversible inactivation of enzymatic and transport properties, and the transferred lipids contain various unsaturated fatty acids (Peters et al., 1981). A technique to circumvent this problem is not available. This complicates the study of lipid effects on the inactivation of membrane-bound enzymes.

To summarize, we suggest two pathways for the photosensitized inactivation of the two ion pumps considered, a fast process originating from photomodification of the cytoplasmic domains by $\mathrm{O}_{2}^{1}$ from the aqueous phase and a slow one, which is caused by a modification of the membrane domain of the ion pumps (Fig. 7). Whether the slow process is due to photosensitized lipid peroxidation, i.e., due to an effect of the lipid environment on the two enzymes, remains to be confirmed by independent approaches in the future. Further studies are also required to clarify the nature of the reactive species $\mathrm{X}$ (Fig. 7B). A prominent candidate is $\mathrm{O}_{2}^{-}$, an important reactive species generated throughout the photodynamic action of rose bengal (Neckers, 1989).

Another important problem to be analyzed in the future is the identification of the reactive sites of the enzymes. This holds also for inactivation of the $\mathrm{Na}, \mathrm{K}-\mathrm{ATPase}$ by free radicals of water radiolysis, which is preferentially induced by $\mathrm{OH}$ radicals, and shows a monoexponential behavior with a pronounced inverse dose rate behavior (Hitschke et al., 1994, Mense et al., 1997). Obviously, radiolytic inactivation - contrary to photodynamic inactivation-proceeds by a single process, which presumably is due to products of lipid peroxidation induced by $\mathrm{OH}$ radicals from the aqueous phase. $\mathrm{Xu}$ and collaborators presented evidence that $\mathrm{OH}$ radical also attacks the ATP binding site of the Na,K-ATPase and of the SR Ca-ATPase (Xu, Zweier \& Becker, 1997, 1997b).

A highly specific oxidative cleavage of $\mathrm{Na}, \mathrm{K}$ ATPase was introduced by Karlish and coworkers (Goldshleger \& Karlish, 1997). They made use of binding of $\mathrm{Fe}^{2+}$ or $\mathrm{Cu}^{2+}$ ions to specific sites of the $\mathrm{Na}, \mathrm{K}$-ATPase $\alpha$-subunit and observed cleavage of peptide bonds close to the metal ions, presumably by $\mathrm{OH}$ radicals generated locally by the Fenton reaction (e.g., $\mathrm{Fe}^{2+} /$ ascorbate $/ \mathrm{H}_{2} \mathrm{O}_{2}$ ) (Shimon, Goldshleger \& Karlish, 1998, Goldshleger \& Karlish, 1999). This technique was applied to probe the proximity between sequences in the membrane helices and cytoplasmic loops of the protein.
In the case of radiolytic and photodynamic enzyme inactivation, however, due to the absence of metal ions, oxidative modifications are less specific and only determined by the nature and by the location of the amino acids forming the structure of the two ion pumps.

\section{Conclusion}

The aim of the present communication is to provide evidence for two different pathways of photosensitized inactivation of the Na,K-ATPase. The most efficient pathway, which underlies the fast inactivation component and has been suggested by previous authors, certainly is due to the action of singlet oxygen from the aqueous phase. The existence of a second, less efficient, presumably membrane-associated pathway, which is described for the first time in this study, may be, however, of greater importance for the photodynamic inactivation of the $\mathrm{Na}, \mathrm{K}$-ATPase in vivo. Due to the high intracellular content of singlet oxygen scavengers, the $\mathrm{Na}, \mathrm{K}$-ATPase in vivo may be expected to behave similarly to our in vitro experiments in the presence of high imidazole concentrations. This means that in vivo the amplitude of the second, slow inactivation process is expected to be predominant.

We thank Milena Roudna and Christine Peinelt for excellent assistance in the preparation of the ATPase-containing membrane preparations.

\section{References}

Apell, H.-J. 2003. Structure-function relationship in p-type ATPases-a biophysical approach. Rev. Physiol. Biochem. Pharmacol. 150: $1-35$

Apell, H.-J., Karlish, S.J.D. 2001. Functional properties of Na,KATPase, and their structural implications, as detected with biophysical techniques. J. Membrane Biol. 180:1-9

Apell, H.-J., Marcus, M., Anner, B.M., Oetliker, H., Läuger, P. 1985. Optical study of active ion transport in lipid vesicles containing reconstituted Na,K-ATPase. J. Membrane Biol 85:49-63

Boldyrev, A., Kurella, E. 1996. Mechanism of oxidative damage of dog kidney $\mathrm{Na} / \mathrm{K}-\mathrm{ATP}$ ase. Biochem Biophys. Res. Commun. 222:483-487

Braughler, J.M., Hall, E.D. 1989. Central nervous system trauma and stroke. I. Biochemical considerations for oxygen radical formation and lipid peroxidation. Free Radio. Biol. Med. 6:289-301

Brown, S.A., Hall, E.D. 1992. Role of oxygen-derived free radicals in the pathogenesis of shock and trauma, with focus on central nervous system injuries. J. Am. Vet. Med. Assoc. 200:1849-1859

Bühler, R., Apell, H.-J. 1995. Sequential potassium binding at the extracellular side of the Na,K-pump. J. Membrane Biol. 145:165-173

Capasso, J.M., Hoving, S., Tal, D.M., Goldshleger, R., Karlish, S.J.D. 1992. Extensive digestion of $\mathrm{Na}^{+}, \mathrm{K}^{+}$-ATPase by specific and nonspecific proteases with preservation of cation occlusion sites. J. Biol. Chem. 267:1150-1158 
Chen, J.W., Zhang, L., Lian, X., Hwang, F. 1992. Effect of hydroxyl radical on $\mathrm{Na}^{+}-\mathrm{K}^{+}$-ATPase activity of the brain microsomal membranes. Cell Biol. Int. Rep. 16:927-936

Dougherty, T.J., Gomer, C.J., Henderson, B.W., Jori, G., Kessel, D., Korbelik, M., Moan, J., Peng, Q. 1998. Photodynamic therapy. J. Natl. Cancer Inst. 90:889-905

Elmoselhi, A.B., Butcher, A., Samson, S.E., Grover, A.K. 1994. Free radicals uncouple the sodium pump in pig coronary artery. Am. J. Physiol. 266:C720-C728

Foote, C.S. 1976. Photosensitized oxidation and singlet oxygen: consequences in biological systems. In: Free Radicals in Biology. Pryor, W.A., editor. pp. 85-134. Academic Press, New York

Girotti, A.W. 1990. Photodynamic lipid peroxidation in biological systems. Photochem. Photobiol 51:497-509

Girotti, A.W. 2001. Photosensitized oxidation of membrane lipids: reaction pathways, cytotoxic effects, and cytoprotective mechanisms. J. Photochem. Photobiol. B 63:103-113

Giulivi, C., Sarcansky, M., Rosenfeld, E., Boveris, A. 1990. The photodynamic effect of rose bengal on proteins of the mitochondrial inner membrane. Photochem. Photobiol. 52:745751

Goldshleger, R., Karlish, S.J. 1999. The energy transduction mechanism of Na,K-ATPase studied with iron- catalyzed oxidative cleavage. J. Biol. Chem. 274:16213-16221

Goldshleger, R., Karlish, S.J.D. 1997. Fe-catalyzed cleavage of the alpha subunit of $\mathrm{Na} / \mathrm{K}$-ATPase: evidence for conformationsensitive interactions between cytoplasmic domains. Proc. Natl. Acad. Sci. USA 94:9596-9601

Grossweiner, L.I., Goyal, G.C. 1984. Photosensitization of liposomes by porphyrins. J. Photochem. 25:253-265

Hall, E.D., Braughler, J.M. 1989. Central nervous system trauma and stroke. II. Physiological and pharmacological evidence for involvement of oxygen radicals and lipid peroxidation. Free Radic. Biol. Med. 6:303-313

Heilmann, C., Brdiczka, D., Nickel, E., Pette, D. 1977. ATPase activities, $\mathrm{Ca}^{2+}$ transport and phosphoprotein formation in sarcoplasmic reticulum subtractions of fast and slow rabbit muscles. Eur. J. Biochem. 81:211-222

Heyse, S., Wuddel, I., Apell, H.-J., Stürmer, W. 1994. Partial reactions of the $\mathrm{Na}, \mathrm{K}-\mathrm{ATPa}$ : determination of rate constants. J. Gen. Physiol. 104:197-240

Hitschke, K., Bühler, R., Apell, H.-J., Stark, G. 1994. Inactivation of the Na,K-ATPase by radiation-induced free radicals. Evidence for a radical-chain mechanism. FEBS. Lett. 353:297-300

Huang, W.H., Wang, Y., Askari, A., Zolotarjova, N., Ganjeizadeh, M. 1994. Different sensitivities of the $\mathrm{Na}^{+} / \mathrm{K}^{+}$-ATPase isoforms to oxidants. Biochim. Biophys. Acta 1190:108-114

Ishibashi, T., Lee, C.I., Okabe, E. 1996. Skeletal sarcoplasmic reticulum dysfunction induced by reactive oxygen intermediates derived from photoactivated rose bengal. J. Pharmacol. Exp. Ther. 277:350-358

Jørgensen, P.L. 1974. Isolation of $\left(\mathrm{Na}^{+}+\mathrm{K}^{+}\right)$-ATPase. Meth. Enzymol. 32:277-290

Kato, K., Shao, Q., Elimban, V., Lukas, A., Dhalla, N.S. 1998. Mechanism of depression in cardiac sarcolemmal $\mathrm{Na}^{+}-\mathrm{K}^{+}$ATPase by hypochlorous acid. Am. J. Physiol. 275:C826-C831

Koufen, P., Brdiczka, D., Stark, G. 2000. Inverse dose-rate effects at the level of proteins observed in the presence of lipids. Int. J. Radiat. Biol. 76:625-631

Kukreja, R.C., Hess, M.L. 1992. The oxygen free radical system: from equations through membrane-protein interactions to cardiovascular injury and protection. Cardiovasc. Res. 26:641655

Lévy, D., Gulik, A., Bluzat, A., Rigaud, J.-L. 1992. Reconstitution of the sarcoplasmic reticulum $\mathrm{Ca}^{2+}$-ATPase: mechanisms of membrane protein insertion into liposomes during reconstitution procedures involving the use of detergents. Biochim. Biophys. Acta 1107:283-298

Mense, M., Stark, G., Apell, H.-J. 1997. Effects of free radicals on partial reactions of the Na,K-ATpase. J. Membrane Biol. 156:63-71

Mishra, O.P., Delivoria-Papadopoulos, M., Cahillane, G., Wagerle, L.C. 1989. Lipid peroxidation as the mechanism of modification of the affinity of the $\mathrm{Na}^{+}, \mathrm{K}^{+}$-ATPase active sites for ATP $, \mathrm{K}^{+}, \mathrm{Na}^{+}$, and strophanthidin in vitro. Neurochem. Res. 14:845-851

Moor, A.C., Lagerberg, J.W., Tijssen, K., Foley, S., Truscott, T.G., Kochevar, I.E., Brand, A., Dubbelman, T.M., VanSteveninck, J. 1997. In vitro fluence rate effects in photodynamic reactions with AIPcS4 as sensitizer. Photochem. Photobiol. 66:860-865

Moore, J.V., West, C.M., Whitehurst, C. 1997. The biology of photodynamic therapy. Phys. Med. Biol. 42:913-935

Neckers, D.C. 1989. Rose bengal. J. Photochem. Photobiol. A 47:129

Pedersen, M., Roudna, M., Beutner, S., Birmes, M., Reifers, B., Martin, H.-D., Apell, H.-J. 2001. Detection of charge movements in ion pumps by a family of styryl dyes. J. Membrane Biol. 185:221-236

Peinelt, C., Apell, H.-J. 2002. Kinetics of the $\mathrm{Ca}^{2+}, \mathrm{H}^{+}$and $\mathrm{Mg}^{2+}$ interaction with the ion-binding sites of the SR-Ca-ATPase. Biophys. J. 82:170-181

Penning, L.C., Tijssen, K., VanSteveninck, J., Dubbelman, T.M. 1994. Hematoporphyrin derivative-induced photodynamic inhibition of $\mathrm{Na}^{+} / \mathrm{K}^{+}$-ATPase in L929 fibroblasts, Chinese hamster ovary cells and T24 human bladder transitional carcinoma cells. Photochem. Photobiol. 59:336-341

Peters, W.H.M., Fleuren-Jakobs, A.M.M., de Pont, J.J.H.H.M., Bonting, S.L. 1981. Studies on $\left(\mathrm{Na}^{+}+\mathrm{K}^{+}\right)$-activated ATPase. XLIX. Content and role of cholesterol and other neutral lipids in highly purified rabbit kidney enzyme preparation. Biochim. Biophys. Acta 649:541-549

Rohn, T.T., Hinds, T.R., Vincenzi, F.F. 1993. Ion transport ATPases as targets for free radical damage. Protection by an aminosteroid of the $\mathrm{Ca}^{2+}$ pump ATPase and $\mathrm{Na}^{+} / \mathrm{K}^{+}$pump ATPase of human red blood cell membranes. Biochem Pharmacol 46:525-534

Rohn, T.T., Hinds, T.R., Vincenzi, F.F. 1996. Inhibition of $\mathrm{Ca}^{2+}-$ pump ATPase and the $\mathrm{Na}^{+} / \mathrm{K}^{+}$-pump ATPase by iron-generated free radicals. Biochem Pharmacol 51:471-476

Schneeberger, A., Apell, H.-J. 2001. Ion selectivity of the cytoplasmic binding sites of the Na,K-ATPase: II. Competition of various cations. J. Membrane Biol. 179:263-273

Schwappach, B., Stürmer, W., Apell, H.-J., Karlish, S.J.D. 1994. Binding of sodium ions and cardiotonic steroids to native and selectively trypsinized $\mathrm{Na}, \mathrm{K}$ pump, detected by charge movements. J. Biol. Chem. 269:21620-21626

Schwartz, A.K., Nagano, M., Nakao, M., Lindenmayer, G.E., Allen, J.C. 1971. The sodium- and potassium-activated adenosinetriphosphatase system. Meth. Pharmacol. 1:361-388

Shao, Q., Matsubara, T., Bhatt, S.K., Dhalla, N.S. 1995. Inhibition of cardiac sarcolemma $\mathrm{Na}^{+}-\mathrm{K}^{+}$-ATPase by oxyradical generating systems. Mol Cell Biochem 147:139-144

Shimon, M.B., Goldshleger, R., Karlish, S.J.D. 1998. Specific $\mathrm{Cu}^{2+}$-catalyzed oxidative cleavage of Na,K-ATPase at the extracellular surface. J. Biol. Chem. 273:34190-34195

Siems, W.G., Hapner, S.J., van Kuijk, F.J. 1996. 4-hydroxynonenal inhibits $\mathrm{Na}^{+}-\mathrm{K}^{+}$-ATPase. Free Radic. Biol. Med. 20:215-223

Stark, G. 1991. The effect of ionizing radiation on lipid membranes. Biochim. Biophys. Acta 1071:103-122 
Straight, R.C., Spikes, J.D. 1985. Photosensitized Oxidation of Biomolecules. In: Singlet Oxygen Frimer, A.A., editor. pp. 91143. CRC Press, Boca Raton, FL

Thomas, C.E., Reed, D.J. 1990. Radical-induced inactivation of kidney $\mathrm{Na}^{+}, \mathrm{K}^{+}$-ATPase: sensitivity to membrane lipid peroxidation and the protective effect of vitamin E. Arch. Biochem Biophys. 281:96-105

Toyoshima, C., Nomura, H. 2002. Structural changes in the calcium pump accompanying the dissociation of calcium. Nature 418:605-611

Tsai, C.S., Godin, J.R., Wand, A.J. 1985. Dye-sensitized photooxidation of enzymes. Biochem J. 225:203-208

Veenhuizen, R.B., Stewart, F.A. 1995. The importance fluence rate in photodynamic therapy: is there a parallel with ion- izing radiation dose-rate effects? Radiother. Oncol. 37:131135

Vinnikova, A.K., Kukreja, R.C., Hess, M.L. 1992. Singlet oxygeninduced inhibition of cardiac sarcolemmal $\mathrm{Na}^{+} \mathrm{K}^{+}$-ATPase. $J$. Mol Cell Cardiol 24:465-470

Xu, K.Y., Zweier, J.L., Becker, L.C. 1997a. Hydroxyl radical inhibits sarcoplasmic reticulum $\mathrm{Ca}^{2+}$-ATPase function by direct attack on the ATP binding site. Circ. Res. 80:76-81

Xu, K.Y., Zweier, J.L., Becker, L.C. 1997b. Oxygen-free radicals directly attack the ATP binding site of the cardiac $\mathrm{Na}^{+}, \mathrm{K}^{+}$ATPase. Ann. N. Y. Acad. Sci. 834:680-683

$\mathrm{Yu}$, X., Carroll, S., Rigaud, J.-L., Inesi, G. 1993. $\mathrm{H}^{+}$countertransport and electrogenicity of the sarcoplasmic reticulum $\mathrm{Ca}^{2+}$ pump in reconstituted proteoliposomes. Biophys. J. 64:1232-1342 